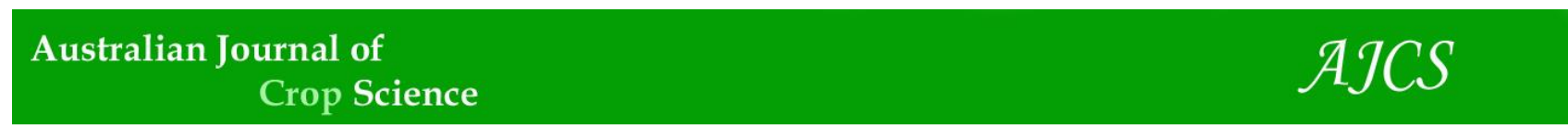

AJCS 13(07):1177-1182 (2019)

ISSN:1835-2707

doi: 10.21475/ajcs.19.13.07.p1687

\title{
Saline water irrigation in semiarid region: II - effects on growth and nutritional status of onions
}

\section{Luiz Guilherme Medeiros Pessoa ${ }^{1}$, Maria Betânia Galvão dos Santos Freire ${ }^{2}$, Renato Lemos dos Santos ${ }^{3}$, Fernando José Freire ${ }^{2}$, Patrícia Ribeiro dos Santos ${ }^{4}$ Márcio Fléquisson Alves Miranda ${ }^{3}$}

\author{
${ }^{1}$ Rural Federal University of Pernambuco, Department of Plant Production, Serra Talhada - PE, Brazil \\ ${ }^{2}$ Rural Federal University of Pernambuco, Department of Agronomy, Recife - PE, Brazil \\ ${ }^{3}$ Federal Institute of Pernambuco, Vitória de Santo Antão - PE, Brazil \\ ${ }^{4}$ Federal Institute of Pernambuco, Barreiros - PE, Brazil
}

*Corresponding author: pessoa.Igm@gmail.com

\begin{abstract}
The use of saline waters for the irrigation of crops such as onion is a common practice in the Brazilian semiarid region. However, the effect of the use of these waters on onion nutrition and growth has been underappreciated. This work aims to evaluate Ca ${ }^{2+}$, $\mathrm{Mg}^{2+}, \mathrm{Na}^{+}, \mathrm{K}^{+}$and $\mathrm{Cl}^{-}$levels and onion growth in two Fluvisols under irrigation with waters of variable electrical conductivity and increasing values of sodium adsorption ratio. A greenhouse experiment was conducted in two Fluvisols cultivated with onion. After transplanting each plant was irrigated with saline waters, in a factorial arrangement $2 \times 3 \times 6$, corresponding to two soils (sandy loam and silt clay loam), three values of electrical conductivity (EC $-200,700$ and 2,000 $\mu \mathrm{S} \mathrm{cm}^{-1}$ ) and six levels of sodium adsorption ratio (SAR - 0, 5, 10, 15, 20 and $\left.25\left(\mathrm{mmol}_{\mathrm{C}} \mathrm{L}^{-1}\right)^{0.5}\right)$. Plants were collected at 90 days after transplanting and onion growth parameters as well $\mathrm{Ca}, \mathrm{Mg}, \mathrm{K}, \mathrm{Na}$ and $\mathrm{Cl}$ levels were each measured. The SAR of the irrigation waters and the soil did not show any significant influence on the onion growth variables or on the levels of the evaluated elements. The increase in salinity of the irrigation water promoted a reduction in the growth variables of the evaluated onion cultivar. Increases in the levels of $\mathrm{Ca}, \mathrm{Na}$ and $\mathrm{Cl}$ as well as a reduction in the level of $\mathrm{K}$ in the onion plant dry matter were all observed with increasing salinity of the irrigation water; however, the $\mathrm{Mg}$ content level was not affected. As the salinity of the irrigation water was the main factor affecting onion growth, an EC of $200 \mu \mathrm{S} \mathrm{cm}^{-1}$ is the limit to promote the best onion growth cultivated in both sandy and silt clay soils.
\end{abstract}

Keywords: Salt stress; saline soils; soil degradation; Allium cepa; irrigation.

Introduction

Agriculture in the semiarid regions around the world is largely comprised of rainfed subsistence farming, which is characterized by low yield due to variation in rainfall quantity and distribution. However, despite the limited amount of water resources in the region, attention given to agricultural water management is very low and its sustainability is under pressure.

Despite its successes, the practice of irrigated agriculture can cause several problems to arise when misused, such as soil salinization. This occurs due to the presence of dissolved salts in the irrigation water that, even at low concentrations, can be absorbed into the soil, making them saline within a few years (de Andrade et al., 2018). Additionally, groundwater salinization has become a global issue mainly in water-scarce areas, particularly in arid and semiarid regions, where groundwater is the primary source of water (Abu-Alrub et al., 2018). In these regions the utilization of saline water for irrigation, as an alternative, is somehow challenging, because it can pose serious threats to agricultural sustainability and food security by creating salt buildup in the root zone if used inappropriately (Hassanli et al., 2016).

One of the most relevant aspects of successful irrigation as an agricultural practice is in respect to the quality of the irrigation water, especially in arid and semiarid regions. The quality of irrigation water refers to the salinity, sodicity and specific toxicity of certain ions. Salinity causes reductions in the plant's water and nutrient availability, limiting growth and yield due to the readily available soluble salts in the soil solution (Rengasamy et al., 2003); sodicity refers to the action of the Na element, with a dispersive effect on soil colloids and is toxic to most plants; finally, the toxicity of specific ions corresponds to the effects caused by Boron, chloride, nitrate and $\mathrm{Na}$, which have a negative impact on growth, yield and quality of the final product (Bar et al., 1997; Wimmer et al., 2003). Moreover, the use of saline irrigation water has an adverse effect on soil-water-plant relations, occasionally severely restricting the normal physiological activity and productive capacity of the crops (Plaut et al., 2013). Under high salinity level, the crop growth, leaf surface expansion, and primary carbon metabolism of many crops are negatively affected due to osmotic effect, water deficit, nutritional imbalance, and oxidative stress (Kim et al., 2008).

Therefore, upon determining the viability of use of irrigation waters, one must take into consideration their chemical 
composition, crop tolerance, soil, water and crop management practices, climatic conditions, irrigation method and drainage conditions (Bustan et al., 2004). In the semiarid region of the Northeast of Brazil, various areas are found with soils which have become salinized through inadequate use of irrigation in these environments, such as the Cachoeira II Irrigated Perimeter located in Serra Talhada - PE (Fernandes et al., 2009).

One of the most common crops in the aforementioned perimeter is onions. However, onion crops are considered to be sensitive to salinity (Sivritepe and Sivritepe, 2007). The cultivar Vale Ouro IPA 11 stands out in the state of Pernambuco, however, little is known in regards to the influence of saline water irrigation on the development of this cultivar or the effect of these waters on the nutritional aspects of the plant. Thus this work has the objective of evaluating $\mathrm{Ca}, \mathrm{Mg}, \mathrm{Na}, \mathrm{K}$ and $\mathrm{Cl}$ levels of the plant's dry matter as well as evaluating the development of onions grown in two Fluvisols under irrigation with waters of variable electrical conductivity and increasing values of sodium adsorption ratio.

\section{Results and Discussion}

Only the EC factor had a significant effect on analyzed variables. This indicates that the salinity exerts a more pronounced effect on the growth and nutrition of the onion than does SAR or soil type.

\section{Effects of saline irrigation on onion growth}

Increasing salinity of the irrigation waters had a significant negative effect on plant development. We observed that the different EC of the irrigation waters influenced each of the evaluated variables, with the exception of leaf dry matter (Table 3). The continuous use of saline water likely provoked an increase in the concentration of salts in the soil solution, leading to negative effects on onion growth variables.

Since onion crops are sensitive to the effect of salts (Ayers and Westcot, 1985), one observes the expressive effect of saline irrigation water with an EC of $2,000 \mu \mathrm{sm}^{-1}$ on all growth variables analyzed throughout the plant cycle. According to Yahya (1998), crop yield diminishes significantly when the content level of salts in the soil solution affect crop water and nutrient absorption, resulting in reductions to growth, development and production, which was observed in the results of this study.

The increase of the salt content level in the irrigation water led to a significant reduction in production of fresh and dry matter of the plants, bulb and roots, as well as the fresh matter of the leaves, in addition to reducing the number and height of leaves and bulb diameter (Table 3 ). These results corroborate with those obtained by Lima and Bull (2008), who observed a reduction in onion growth variables with the increase of salinity from 0 to $10 \mathrm{dS} \mathrm{m}^{-1}$. Mangal and Lal (1989) also registered a severe reduction in the number of leaves per plant, leaf height and root development of onions with increasing soil salinity. Similarly, Lima et al. (2006) observed drastic reductions in the dry matter weight of the shoot system and bulb of onion plants with the increase of salinity from 0.3 to $8.0 \mathrm{dS} \mathrm{m}^{-1}$. Chang and Randle (2004) verified that increasing $\mathrm{NaCl}$ concentrations reduced bulb fresh weight ( 350 to $44.8 \mathrm{~g}$ per bulb) and leaf fresh weight
(156 to $21.6 \mathrm{~g}$ per plant).

The increase of the Sodium Adsorption Ratio (SAR) of the irrigation waters had no significant effect on onion growth variables, unlike rising EC. Thus, even with $\mathrm{Na}$ as the predominant ion in irrigation water, if the EC is low, the onion crop may have satisfactory production. It was not possible to adjust regression models for onion growth variables in terms of irrigation water SAR, indicating that, under the conditions tested, the use of a higher SAR does not affect onion development in the same way as increasing salinity.

\section{Effects of saline irrigation on onion nutritional status}

$\mathrm{Ca}, \mathrm{Mg}, \mathrm{Na}, \mathrm{K}$ and $\mathrm{Cl}$ levels in the onion plant compartments were each evaluated in relation to irrigation water salinity, verifying an effect on $\mathrm{Ca}, \mathrm{Na}$ and $\mathrm{Cl}$ levels in the onion plant bulb with the use of higher EC water (Table 4). There was an increase in the levels of these elements in proportion to increasing irrigation water salinity, in which the lowest levels in the bulbs were observed in plants irrigated with the least saline irrigation waters.

Significant differences were not observed for $\mathrm{K}$ or $\mathrm{Mg}$ levels in the bulbs in relation to irrigation water salinity, although higher levels in bulbs were observed for plants irrigated with less saline water. These results suggest that the predominance of $\mathrm{Ca}^{2+}$ and $\mathrm{Na}^{+}$ions in the irrigation waters and, consequently, in the soil solution, may be promoting a nutritional imbalance in the onion plants, affecting $\mathrm{K}$ and $\mathrm{Mg}$ absorption through the competition between these elements and the $\mathrm{Ca}^{2+}$ and $\mathrm{Na}^{+}$present in the saline irrigation waters. Similar results were cited by Ojala et al. (1983), who reported reductions in K concentration in onion bulbs with increaseing irrigation water salinity. For Thomas (1980), soil salinization or irrigation with saline waters, generally with high $\mathrm{NaCl}$ or $\mathrm{CaCl}_{2}$ levels, increases the concentration of those specific cations in the plant, with a concomitant reduction of other cations.

The levels of the elements in the dry matter of the onion plant bulbs submitted to irrigation waters with low EC (200 $\mu \mathrm{Cm}^{-1}$ ) were observed to follow order: $\mathrm{K}>\mathrm{Ca}>\mathrm{Cl}>\mathrm{Mg}>$ $\mathrm{Na}$, results that concur with Vidigal et al. (2010). In these plants, the proportions of the levels of the elements in the dry matter of the bulbs corresponded to $60.79 \% \mathrm{~K} ; 21.57 \%$ $\mathrm{Ca} ; 7.22 \% \mathrm{Cl} ; 6.48 \% \mathrm{Mg}$; and $3.94 \% \mathrm{Na}$. On the other hand, in the dry matter of the bulbs of plants irrigated with $\mathrm{EC}$ of 700 and $2,000 \mu \mathrm{S} \mathrm{cm}^{-1}$, the levels of the elements presented the order: $\mathrm{K}>\mathrm{Ca}>\mathrm{Cl}>\mathrm{Na}>\mathrm{Mg}$. Thus, with the increasing $\mathrm{EC}$ of the irrigation waters, $\mathrm{Na}$ levels were higher than those of $\mathrm{Mg}$ in the onion bulb dry matter, likely contributing to the reduction of this plant component (Table 3).

In relation to the elements analyzed in the dry matter of the plant bulbs submitted to irrigation water with an EC of 700 $\mu \mathrm{S} \mathrm{cm}^{-1}, \mathrm{~K}$ corresponded to $44.69 \%$; $\mathrm{Ca}$ to $31.42 \% ; \mathrm{Cl}$ to $12.48 \%$; $\mathrm{Na}$ to $6.70 \%$; and $\mathrm{Mg}$ to $4.73 \%$; while in the dry matter of the plant bulbs submitted to irrigation with an EC of $2,000 \mu \mathrm{S} \mathrm{cm}^{-1}$ the proportions were: $35.23 \% \mathrm{~K} ; 32.85 \% \mathrm{Ca}$; $15.53 \% \mathrm{Cl} ; 11.68 \% \mathrm{Na}$; and $4.71 \% \mathrm{Mg}$, with greater proportions of $\mathrm{Cl}$ and $\mathrm{Na}$, and lower proportions of $\mathrm{K}$ and Mg. Wiedenfeld (1994) verified levels of $K$ in bulbs corresponding to $43.7 \%, \mathrm{Ca}$ to $39.3 \%$ and $\mathrm{Mg}$ to $52.8 \%$ of total nutrients. This author related that most of the $\mathrm{K}$ and $\mathrm{Ca}$ accumulate in the shoots onion while the highest levels of 
Table 1. Physical attributes of the two Fluvisols $(0-20 \mathrm{~cm})$ used in the experiment.

\begin{tabular}{|c|c|c|c|c|c|c|c|c|c|c|}
\hline Soil texture & Sand & Silt & Clay & WDC $^{1}$ & $\mathrm{FI}^{2}$ & $\mathrm{DI}^{3}$ & $\mathrm{BD}^{4}$ & $\mathrm{PD}^{5}$ & TP6 & $\mathrm{K}_{0}{ }^{7}$ \\
\hline & & $\mathrm{g} \mathrm{kg}^{-1}$ & - & & $-\%$ & & $-\mathrm{g} \mathrm{cm}^{-3}$ & & $\%$ & $\mathrm{~cm} \mathrm{~h}^{-1}$ \\
\hline Sandy loam & 546.8 & 220.0 & 233.2 & 169.6 & 27.27 & 72.73 & 1.34 & 2.50 & 46 & 3.89 \\
\hline Silty clay loam & 191.6 & 420.0 & 388.4 & 289.6 & 25.44 & 74.56 & 1.21 & 2.70 & 55 & 0.33 \\
\hline
\end{tabular}

${ }^{1}$ WDC: Water Dispersible Clay; ${ }^{2} \mathrm{FI}$ : Flocculation Index; ${ }^{3} \mathrm{DI}$ : Dispersion Index; ${ }^{4} \mathrm{BD}$ : Bulk Density; ${ }^{5} \mathrm{PD}$ : Particle Density; ${ }^{6} \mathrm{TP}:$ Total Porosity; ${ }^{7} \mathrm{~K}_{0}$ : Saturated Hydraulic Conductivity.

Table 2. Chemical attributes of the two Fluvisols $(0-20 \mathrm{~cm})$ used in the experiment.

\begin{tabular}{|c|c|c|}
\hline \multirow{2}{*}{ Attribute } & \multicolumn{2}{|c|}{ Soil texture } \\
\hline & Sandy loam & Silty clay loam \\
\hline \multicolumn{3}{|l|}{ Exchangeable complex } \\
\hline $\mathrm{pH}$ (1:2.5 - soil:water) & 7.3 & 7.1 \\
\hline $\mathrm{Ca}^{2+}\left(\mathrm{cmol}_{\mathrm{c}} \mathrm{dm}^{-3}\right)$ & 7.43 & 8.54 \\
\hline $\mathrm{Mg}^{2+}\left(\mathrm{cmol}_{\mathrm{c}} \mathrm{dm}^{-3}\right)$ & 2.17 & 3.23 \\
\hline $\mathrm{Na}^{+}\left(\mathrm{cmol}_{\mathrm{c}} \mathrm{dm}^{-3}\right)$ & 0.07 & 0.30 \\
\hline $\mathrm{K}^{+}\left(\mathrm{cmol}_{\mathrm{c}} \mathrm{dm}^{-3}\right)$ & 0.57 & 0.49 \\
\hline $\mathrm{CEC}^{1}\left(\mathrm{cmol}_{\mathrm{c}} \mathrm{dm}^{-3}\right)$ & 11.63 & 15.86 \\
\hline $\operatorname{ESP}^{2}(\%)$ & 0.60 & 1.89 \\
\hline$P_{\text {Bray }-1^{3}}\left(\mathrm{mg} \mathrm{dm}^{-3}\right)$ & 43.75 & 23.66 \\
\hline \multicolumn{3}{|l|}{ Soluble complex } \\
\hline $\mathrm{pH}$ & 8.3 & 7.4 \\
\hline $\mathrm{EC}^{4}\left(\mathrm{dS} \mathrm{m^{-1 }}\right)$ & 0.86 & 0.85 \\
\hline $\mathrm{Ca}^{2+}\left(\mathrm{mmol}_{\mathrm{c}} \mathrm{L}^{-1}\right)$ & 3.73 & 5.12 \\
\hline $\mathrm{Mg}^{2+}\left(\mathrm{mmol}_{\mathrm{c}} \mathrm{L}^{-1}\right)$ & 2.89 & 3.70 \\
\hline $\mathrm{Na}^{+}\left(\mathrm{mmol}_{\mathrm{c}} \mathrm{L}^{-1}\right)$ & 1.97 & 2.46 \\
\hline $\mathrm{K}^{+}\left(\mathrm{mmol}_{\mathrm{c}} \mathrm{L}^{-1}\right)$ & 1.42 & 0.61 \\
\hline $\mathrm{Cl}^{-}\left(\mathrm{mmol}_{\mathrm{c}} \mathrm{L}^{-1}\right)$ & 3.00 & 3.00 \\
\hline $\mathrm{HCO}_{3}-\left(\mathrm{mmol}_{\mathrm{c}} \mathrm{L}^{-1}\right)$ & 2.16 & 1.76 \\
\hline $\mathrm{CO}_{3}{ }^{2-}\left(\mathrm{mmol}_{\mathrm{c}} \mathrm{L}^{-1}\right)$ & 1.20 & 0.00 \\
\hline $\operatorname{SAR}^{5}\left(\mathrm{mmol}_{\mathrm{c}} \mathrm{L}^{-1}\right)^{0,5}$ & 1.08 & 1.17 \\
\hline
\end{tabular}

${ }^{1} \mathrm{CEC}$ : Cation Exchange Capacity; ${ }^{2}$ ESP: Exchangeable Sodium Percentage; ${ }^{3} \mathrm{P}$ Bray - 1: Phosphorous extracted by Bray-1; ${ }^{4}$ EC: Electrical Conductivity; ${ }^{5}$ SAR: Sodium Adsorption Ratio.

Table 3. Production of plant fresh matter (PFM), leaf fresh matter (LFM), bulb fresh matter (BFM), root fresh matter (RFM), plant dry matter (PDM), leaf dry matter (LDM), bulb dry matter (BDM), root dry matter (RDM), number of leaves (NL), leaf height (LH) and mean bulb diameter (MBD) at ninety days after transplanting, in terms of the electrical conductivity (EC) of the irrigation water.

\begin{tabular}{|c|c|c|c|c|}
\hline \multirow{2}{*}{ Characteristic evaluated } & \multicolumn{3}{|c|}{$\mathrm{CE}\left(\mu \mathrm{S} \mathrm{cm^{-1 } )}\right.$} & \multirow{2}{*}{ CV (\%) } \\
\hline & 200 & 700 & 2.000 & \\
\hline LFM (g) & $31.57 \mathrm{~A}$ & $27.72 \mathrm{~B}$ & $18.04 \mathrm{C}$ & 34.03 \\
\hline RFM (g) & $1.52 \mathrm{~A}$ & $1.90 \mathrm{~A}$ & $0.74 \mathrm{~B}$ & 190.94 \\
\hline PDM (g) & $6.21 \mathrm{~A}$ & $5.20 \mathrm{~B}$ & $3.82 \mathrm{C}$ & 43.68 \\
\hline LDM (g) & $2.80 \mathrm{~A}$ & $2.35 \mathrm{~A}$ & $2.20 \mathrm{~A}$ & 86.22 \\
\hline $\mathrm{NL}$ & $7.83 \mathrm{~A}$ & $6.96 \mathrm{~B}$ & $5.87 \mathrm{C}$ & 21.39 \\
\hline $\mathrm{LH}(\mathrm{cm})$ & $54.10 \mathrm{~A}$ & $50.12 \mathrm{~B}$ & $45.28 \mathrm{C}$ & 10.49 \\
\hline $\mathrm{MBD}(\mathrm{mm})$ & $35.84 \mathrm{~A}$ & $32.92 \mathrm{~B}$ & $25.86 \mathrm{C}$ & 17.40 \\
\hline
\end{tabular}

* Means followed by the same letter in the line differ significantly by the Scott Knott test at the level of $5 \%$ probability.

Table 4. Content levels of calcium, magnesium, sodium, potassium and chlorine in the dry matter of roots, bulbs and leaves of the onion plants in terms of electrical conductivity $(\mathrm{EC})$ of the irrigation water.

\begin{tabular}{|c|c|c|c|c|c|}
\hline $\begin{array}{l}\mathrm{EC} \\
\left(\mu \mathrm{S} \mathrm{cm}^{-1}\right)\end{array}$ & $\mathrm{Ca}$ & $\mathrm{Mg}$ & $\mathrm{Na}$ & $\mathrm{K}$ & $\mathrm{Cl}$ \\
\hline \multicolumn{6}{|l|}{ Root } \\
\hline 200 & $6.99 \mathrm{C}$ & $3.45 \mathrm{~B}$ & $21.59 \mathrm{C}$ & $30.97 \mathrm{~A}$ & $10.10 \mathrm{C}$ \\
\hline 700 & $8.86 \mathrm{~B}$ & $3.77 \mathrm{~B}$ & $25.34 \mathrm{~B}$ & $30.63 \mathrm{~A}$ & $13.05 \mathrm{~B}$ \\
\hline 2.000 & $10.88 \mathrm{~A}$ & $4.31 \mathrm{~A}$ & $28.98 \mathrm{~A}$ & $28.11 \mathrm{~A}$ & $15.07 \mathrm{~A}$ \\
\hline CV (\%) & 34.48 & 25.67 & 26.23 & 23.07 & 32.97 \\
\hline \multicolumn{6}{|l|}{ Bulb } \\
\hline$\overline{200}$ & $5.53 \mathrm{C}$ & $1.66 \mathrm{~A}$ & $1.01 \mathrm{C}$ & $15.58 \mathrm{~A}$ & $1.85 \mathrm{C}$ \\
\hline 700 & $8.44 \mathrm{~B}$ & $1.27 \mathrm{~A}$ & $1.80 \mathrm{~B}$ & $12.00 \mathrm{~A}$ & $3.35 \mathrm{~B}$ \\
\hline 2.000 & $11.02 \mathrm{~A}$ & $1.58 \mathrm{~A}$ & $3.92 \mathrm{~A}$ & $11.82 \mathrm{~A}$ & $5.21 \mathrm{~A}$ \\
\hline CV (\%) & 45.30 & 66.60 & 56.08 & 70.12 & 38.32 \\
\hline \multicolumn{6}{|l|}{ Leaf } \\
\hline$\overline{200}$ & $8.88 \mathrm{~B}$ & $2.43 \mathrm{~A}$ & $5.30 \mathrm{C}$ & $25.38 \mathrm{~A}$ & $5.71 \mathrm{C}$ \\
\hline 700 & $8.72 \mathrm{~B}$ & $2.28 \mathrm{~A}$ & $10.03 \mathrm{~B}$ & $21.23 \mathrm{~B}$ & $9.09 \mathrm{~B}$ \\
\hline 2.000 & $10.66 \mathrm{~A}$ & $2.39 \mathrm{~A}$ & $18.78 \mathrm{~A}$ & $23.06 \mathrm{~B}$ & $14.41 \mathrm{~A}$ \\
\hline CV (\%) & 20.31 & 17.64 & 34.27 & 21.80 & 15.63 \\
\hline
\end{tabular}

*Means followed by the same letter in the column within each plant component differ significantly by the Scott Knott test at the level of $5 \%$ probability. 
$\mathrm{Mg}$ are found in the bulb, disagreeing with the results obtained in this work.

There was a reduction in $\mathrm{K}$ content level in onion bulb dry matter, with levels reduced by half with EC of irrigation water increasing from 200 to $2,000 \mu \mathrm{S} \mathrm{cm} \mathrm{cm}^{-1}$. The disproportionate presence of $\mathrm{Na}^{+}$in both cellular and extracellular compartments negatively impacts the acquisition of essential nutrients such as $\mathrm{K}^{+}$(Maathuis, 2006). The Mg levels were also reduced increasing EC of the irrigation water, although in lesser proportions than that found for K (Table 4). On the other hand, an increase in the $\mathrm{Ca}, \mathrm{Cl}$ and $\mathrm{Na}$ content levels was observed in the onion bulb dry matter, possibly through the supply of these elements in the irrigation waters that were prepared with $\mathrm{NaCl}$ and $\mathrm{CaCl}_{2}$ salts. This indicates the risk of the use of saline waters for the nutritional balance of onions and, consequently, for their productivity, measured by the evaluated growth variables (Table 3 ).

In leaf dry matter, only the $\mathrm{Mg}$ content levels were unchanged with increasing irrigation water salinity, while the $\mathrm{Ca}, \mathrm{Na}$ and $\mathrm{Cl}$ content levels rose probably due to the presence of these elements in the salts with which the waters were prepared. $\mathrm{K}$ levels in the onion leaf dry matter declined with increasing irrigation water salinity, as occurred with the levels found in the dry matter of the bulbs. Greater content levels of the elements were detected in the dry matter of the leaves than in the bulbs, indicating the retention of greater concentrations of these elements in the leaves of plants submitted to saline stress, with the exception of $\mathrm{Ca}$, in which the content levels found in the bulbs were similar to those detected in the leaves. Similar results were obtained by Lima et al. (2006).

In the dry matter of the leaves of the plants irrigated with the least saline irrigation water ( $E C$ of $200 \mu \mathrm{S} \mathrm{cm}-1$ ), the levels of the examined elements followed the order: $\mathrm{K}>\mathrm{Ca}$ $>\mathrm{Cl}>\mathrm{Na}>\mathrm{Mg}$, in which $\mathrm{K}$ represented $53.21 \%$; Ca $18.62 \%$; $\mathrm{Cl} 11.97 \%$; $\mathrm{Na} 11.11 \%$; and $\mathrm{Mg}$ 5.09\%. These results also corroborate with those obtained by Vidigal et al. (2010). Even with this lower saline concentration, the predominance of $\mathrm{Na}$ over $\mathrm{Mg}$ was observed in the onion leaves, which did not occur with the bulbs.

$\mathrm{Na}$ concentration was found to be greater than $\mathrm{Ca}, \mathrm{Mg}$ and $\mathrm{Cl}$ in the leaves of the plants irrigated with the waters of EC 700 and $2,000 \mu \mathrm{S} \mathrm{cm}^{-1}$, with the following order of the content levels of the elements: $\mathrm{K}>\mathrm{Na}>\mathrm{Cl}>\mathrm{Ca}>\mathrm{Mg}$. Proportionally, in the leaves of the plants irrigated with irrigation waters of EC $700 \mu \mathrm{S} \mathrm{cm} \mathrm{cm}^{-1}, \mathrm{~K}$ represented $41.34 \%$; $\mathrm{Na} 19.53 \%$; $\mathrm{Cl} 17.71 \%$; Ca $16.98 \%$; and $\mathrm{Mg}$ 4.44\%. Marcussi et al. (2004) also found similar levels working with nitrogen and potassium fertigation in onion crops. Thus, increases in the content levels of $\mathrm{Na}$ and $\mathrm{Cl}$ were observed, as well as reductions in the content levels of $\mathrm{K}, \mathrm{Ca}$ and $\mathrm{Mg}$ in relation to the content levels of these same elements in the leaves of the plants irrigated with the water with EC of $200 \mu \mathrm{S} \mathrm{cm}^{-1}$. These results were further impacted by raising the salinity of the waters to the $\mathrm{EC}$ of $2,000 \mu \mathrm{S} \mathrm{cm}^{-1}$, in which the $\mathrm{K}$ level corresponded to $33.28 \%$ of the leaf dry matter; that of $\mathrm{Na}$ to $27.1 \%$; that of $\mathrm{Cl}$ to $20.79 \%$; that of $\mathrm{Ca}$ to $10.66 \%$; and that of $\mathrm{Mg}$ to $3.45 \%$.

Greater reductions in the levels of $\mathrm{K}, \mathrm{Ca}$ and $\mathrm{Mg}$ as well as increases in $\mathrm{Na}$ and $\mathrm{Cl}$ content levels were all observed, as had been detected in the leaves of the plants irrigated with waters of intermediate salinity $\left(700 \mu \mathrm{S} \mathrm{cm}^{-1}\right)$. According to Fernandes et al. (2002), in the presence of an elevated external concentration of $\mathrm{Na}$, absorption of $\mathrm{K}$ and $\mathrm{Ca}$ may be inhibited by competition with $\mathrm{Na}$, causing a deficiency of these nutrients and an increase in the content level of $\mathrm{Na}$ in the plant cells. Caldwell et al. (1994) defined ranges of adequate nutrient content levels in leaves for the onion crop where, for $\mathrm{Ca}, \mathrm{Mg}$ and $\mathrm{K}$, these content levels should vary between 9 and $35 \mathrm{~g} \mathrm{~kg}^{-1}, 1.8$ and $5.0 \mathrm{~g} \mathrm{~kg}^{-1}$ and 20 and $50 \mathrm{~g}$ $\mathrm{kg}^{-1}$ respectively. Despite the elevated contents of $\mathrm{Na}$ observed in the plant leaves in the present study, only Ca did not fit within these limits for plants irrigated with less saline waters (200 and $700 \mu \mathrm{S} \mathrm{cm}^{-1}$ ) (Table 4). This may be explained by the high level of $\mathrm{Ca}, \mathrm{Mg}$ and $\mathrm{K}$ in the soils (Table 2), which were capable of meeting the needs of the plant for these nutrients. However, elevated concentrations of sodium may limit plant growth (Table 3 ).

In the roots, the levels of $\mathrm{Na}, \mathrm{Ca}$ and $\mathrm{Cl}$ also increased with increasing irrigation water salinity, similar to that which occurred in the bulb and the leaves (Table 4). In regard to $\mathrm{Mg}$, the content levels increased only in the roots of the plants irrigated with the water of greatest salinity, which was not observed for either the bulbs or leaves; and the $\mathrm{K}$ content levels were not statistically different among the roots of the plants irrigated with the waters of different values of EC.

In the root dry matter of the plants irrigated with the waters of EC of 200 and $700 \mu \mathrm{S} \mathrm{cm}-1$, the content levels of the elements were found in the following decreasing order: $\mathrm{K}>$ $\mathrm{Na}>\mathrm{Cl}>\mathrm{Ca}>\mathrm{Mg}$, with $\mathrm{K}$ representing $42.37 \%, \mathrm{Na} 29.53 \%$, $\mathrm{Cl} 13.82 \%$, Ca $9.56 \%$ and $\mathrm{Mg} 4.72 \%$, in the roots of the plants irrigated with the water of EC $200 \mu \mathrm{S} \mathrm{cm}^{-1}$. In the roots of the plants irrigated with the waters of EC of $700 \mu \mathrm{S} \mathrm{cm}^{-1}$, the $\mathrm{K}$ levels corresponded to $37.51 \%$, Na $31.04 \%, \mathrm{Cl} 15.98 \%$, Ca $10.85 \%$ and $\mathrm{Mg} 4.62 \%$. In the roots of the plants submitted to irrigation with waters of EC of $2,000 \mu \mathrm{S} \mathrm{cm}^{-1}$, the content levels of the elements were found in the sequence: $\mathrm{Na}>\mathrm{K}>$ $\mathrm{Cl}>\mathrm{Ca}>\mathrm{Mg}$, in which $\mathrm{Na}$ corresponded to $33.18 \%, \mathrm{~K}$ $32.18 \%, \mathrm{Cl} 17.25 \%, \mathrm{Ca} 12.46 \%$ and $\mathrm{Mg} 4.93 \%$. Thus, increasing the salinity of the irrigation water to this level caused the $\mathrm{Na}$ content level to surpass that of $\mathrm{K}$ in the onion plant roots, rising above all the rest.

Considering analysis of the entire plant, greater levels of the elements were observed in the root dry matter, followed by the leaves and bulb, regardless of the salinity of the water applied (Table 4). In general, $\mathrm{K}$ was the element found in greatest concentration in the plant components evaluated, except in some cases with irrigation water with elevated EC, in which $\mathrm{Na}$ presented at a higher level. High levels of $\mathrm{Cl}$ were also detected. These high levels of $\mathrm{Na}$ and $\mathrm{Cl}$ are probably due to the composition of the irrigation water, which was synthesized from the salts $\mathrm{NaCl}$ and $\mathrm{CaCl}_{2}$, simulating the waters used for irrigation in the Cachoeira II Irrigated Perimeter (Fernandes, 2009).

Zink (1962) observed accumulations of nutrients in onion plants following a decreasing order: $\mathrm{K}>\mathrm{N}>\mathrm{Ca}>\mathrm{P}>\mathrm{Na}>$ $\mathrm{Mg}$. In the present study, in spite of $\mathrm{N}$ not having been evaluated, we observed that $\mathrm{K}$ was the predominant element in the dry matter of the onion plants, regardless of the EC of the irrigation water. Similar data was found by Porto et al. (2007), who detected $K$ as the nutrient accumulated in greatest quantity by onions. According to 
Taiz and Zeiger (2004), $\mathrm{K}$ performs a vital function in the regulation of the osmotic potential of the plant cells and in the opening and closing of the plant stomata, making it a fundamental element for the plant's capacity to withstand environments under water and saline stress.

\section{Materials and methods}

\section{Plant materials}

Onion seedlings of the Vale Ouro IPA 11 cultivar were sown into trays with commercial substrate and transplanted to the pots after 30 days. At the time of transplanting, fertilization was carried out across all the treatments, in order to meet the needs of the crop, according to the chemical analyzes of the soils and the nutritional requirements of the onion, following the guidelines provided in the Recommendation Bulletin of Corrective and Fertilizers of the State of Pernambuco (IPA, 2008). Phosphate fertilization was carried out at a depth of $10 \mathrm{~cm}$, utilizing triple superphosphate (45 $\mathrm{kg} \mathrm{ha}^{-1}$ of $\left.\mathrm{P}_{2} \mathrm{O}_{5}\right)$ as the source of $\mathrm{P}$, potassium sulphate $(45 \mathrm{~kg}$ $\mathrm{ha}^{-1} \mathrm{~K}_{2} \mathrm{O}$ ) as potassium source, and nitrogen in the form of urea (45 kg ha-1 of $\mathrm{N}$ ), with values adjusted for the soil volumes of the vessels. Micronutrients were supplied by the "Fertilizer Base" leaf fertilizer, by foliar spray recommended for onion cultivation, at a ratio of $200 \mathrm{~mL}$ of the product to $100 \mathrm{~L}$ of water. Irrigation with the respective saline waters was initiated at seedling planting.

\section{Description of the experimental area}

Two soils were collected from the superficial layer $(0-20 \mathrm{~cm})$ in the Irrigated Perimeter Cachoeira II, Serra Talhada-PE, located in the semiarid region of Brazil. Two non-saline and non-sodic Fluvisols were selected due their being representative of the Irrigated Perimeter. One soil was of the textural class sandy loam while the other was silty clay loam. The soils were air-dried, sutured and sieved in a $2 \mathrm{~mm}$ mesh for physical and chemical characterization analyzes (Tables 1 and 2); and then in $4 \mathrm{~mm}$ mesh for the assembly of the experiment.

\section{Experimental design and description of treatments}

The experiment was conducted in a greenhouse at the Agronomy Department of the Federal Rural University of Pernambuco, Brazil. Two types of soils were irrigated with water at three values of electrical conductivity (EC) and six levels of sodium adsorption ratio (SAR), combined as salinity treatments. Thus, the experiment consisted of a complete factorial arrangement $2 \times 3 \times 6$ (two soils, three EC levels and six SAR levels), in four replicates, for a total of 144 experimental units. The experimental design consisted of randomized blocks, with one replicate per block.

Irrigation waters with different salinities were prepared in the laboratory to represent the mean salinity of the water found in sources used within the irrigated perimeter, according to Fernandes et al. (2009), with electrical conductivities of irrigation water (EC) of 200, 700 and 2,000 $\mu \mathrm{S} \mathrm{cm}{ }^{-1}$ and SAR of $0,5,10,15,20$ and $25\left(\text { mmol }_{\mathrm{c}} \mathrm{L}^{-1}\right)^{0.5}$, totaling 18 types of water. These irrigation waters were elaborated from the salts $\mathrm{NaCl}$ and $\mathrm{CaCl}_{2} \cdot 2 \mathrm{H}_{2} \mathrm{O}$.
The soils were homogenized and packed in polyethylene pots with $6.5 \mathrm{~kg}$ of soil each, which were then saturated with their respective salt water. Irrigation was performed with a water blade greater than the soil retention capacity, providing leaching, which was performed manually on alternating days.

\section{Plant measurements}

At 90 days after transplanting, plants were collected and measurements taken for both bulb diameter and leaf height. The total number of leaves was counted and measurements were taken for fresh mass of whole plants, leaves, roots and bulb. Then, collected samples were packed in paper bags and transported for drying in a forced air circulation laboratory oven at $65^{\circ} \mathrm{C}$ until reaching constant weight, measurements were taken for dry matter weight and then the material was chopped and subjected to nitro-perchloric extraction in order to determine the $\mathrm{Ca}, \mathrm{Mg}, \mathrm{K}, \mathrm{Na}$ levels (Malavolta et al., 1989) in the roots, bulb and leaves. Finally, $\mathrm{Cl}$ was extracted with water (Malavolta et al., 1989).

\section{Statistical analysis}

Data were submitted to analysis of variance and Scott Knott's mean test at the $5 \%$ probability level, for comparison of means of the different EC treatments.

\section{Conclusion}

Increasing irrigation water salinity promoted a reduction in the growth variables of the onion cultivar evaluated, indicating that saline waters limit the productivity of this crop. Reductions in the total number and height of the leaves of the plants submitted to irrigation with waters of elevated electrical conductivity promoted a reduction in onion bulb growth which, at the most elevated level, had a mean diameter lower to that which is commercially acceptable. In addition to the reduction in the plant growth variables, increases in $\mathrm{Ca}, \mathrm{Na}$ and $\mathrm{Cl}$ levels as well as a reduction of $\mathrm{K}$ in the dry matter of the onion plants was observed with increasing irrigation water salinity; however, the $\mathrm{Mg}$ content level unaffected. Despite the content levels of the $\mathrm{Ca}, \mathrm{Mg}$ and $\mathrm{K}$ nutrients in the leaves being adequate, $\mathrm{Na}$ was predominant in the plants irrigated with the waters of greater salinity, which may have promoted the observed growth decreases. The sodium adsorption ratio of the irrigation waters did not have a significant influence on onion growth variables or on the levels of the evaluated elements in the dry matter of the plants, leading to the conclusion that the most expressive negative effects of the salts are more related to the saline concentrations than to the types of salts dominant in the waters. Regardless of the salinity of the irrigation water, the part of the onion plant with the greatest element concentrations were the roots, with higher content levels of $\mathrm{Ca}, \mathrm{Mg}, \mathrm{K}, \mathrm{Na}$ and $\mathrm{Cl}$ than found in either the bulbs or leaves. As the salinity of the irrigation water was the main factor affecting onion growth, an EC of $200 \mu \mathrm{S} \mathrm{cm}^{-1}$ is the limit to promote the best onion growth cultivated in both sandy and silt clay soils. 


\section{Acknowledgements}

The authors wish to thank the National Council for Scientific and Technological Development (CNPq).

\section{References}

Abu-Alrub I, Marcum KB, Kabir N, Aran A, Hammadi MA (2018) Productivity and nutritional value of four forage grass cultivars compared to Rhodes grass irrigated with saline water. Aust J Crop Sci. 12 (02): 203-209.

Ayers RS, Westcot DW (1985) Water quality for agriculture. Irrigation and Drainage Paper, 1st edn. FAO, Rome n. 29.

Bar Y, Apelbaum A, Kafkafi U, Goren R (1997) Relationship between chloride and nitrate and its effect on growth and mineral composition of avocado and citrus plants. J Plant Nutr. 20 (6): 715-731.

Bustan A, Sagi M, De Malach Y, Pasternak D (2004) Effects of saline irrigation water and heat waves on potato production in an arid environment. Field Crop Res. 90 (2): 275-285.

Caldwell JN, Sumner ME, Vavrina CS (1994) Development and testing of preliminary foliar DRIS norms for onions. Hortic Sci. 29 (12): 1501-1504.

Chang PT, Randle WM (2004) Sodium chloride in nutrient solutions can affect onion growth and flavor development. Hortic Sci. 39 (6): 1416-1420.

de Andrade JJ, de Oliveira FJM, Pessoa LGM, Nascimento SAS, de Souza ES, Barros Júnior G, Miranda MFA, de Oliveira AC, Freire MBGS (2018) Effects of elemental sulfur associated with gypsum on soil salinity attenuation and sweet sorghum growth under saline water irrigation. Aust J Crop Sci. 12 (02): 221-226.

Fernandes AR, Carvalho JG, Curi N, Pinto JEBP, Guimarães PTG (2002) Nutrição mineral de mudas de pupunheira sob diferentes níveis de salinidade. Pesqui Agropecu Bras. 37 (11): 1613-1619.

Fernandes JG, Freire MBGS, Cunha JC, Galvíncio JD, Correa MM, Santos PR (2009) Qualidade físico-química das águas utilizadas no Perímetro Irrigado Cachoeira II, Serra Talhada, Pernambuco. Revista Brasileira de Ciências Agrárias. 4 (1): 27-34.

Hassanli M, Ebrahimian H, Mohammadi E, Rahimi A, Shokouhi A (2016) Simulating maize yields when irrigating with saline water, using the AquaCrop, SALTMED, and SWAP models. Agr Water Manage. 176: 91-99.

IPA - Instituto Agronômico de Pernambuco (2008) Recomendações de adubação para o estado de Pernambuco, 2nd edn. IPA, Recife.

Kim H, Fonseca JM, Choi J, Kubota C, Kwon DY (2008) Salt in irrigation water affects the nutritional and visual properties of romaine lettuce (Lactuca sativa L.). J Agr Food Chem. 56: 3772-3776.
Lima MDB, Bull LT (2008) Produção de cebola em solo salinizado. Rev Bras Eng Agri Amb. 12 (13): 231 - 235.

Lima MDB, Bull LT, Grassi Filho H (2006) Índices fisiológicos e absorção de nutrientes pela cultura da cebola submetida a condições de salinidade e estresse hídrico. Irriga. 11 (3): 356-366.

Maathuis FJM (2006) The role of monovalent cation transporters in plant responses to salinity. J Exp Bot. 57 (5): $1137-1147$.

Malavolta E, Vitti GC, Oliveira SA. (1989) Avaliação do estado nutricional das plantas: princípios e aplicações, 1st edn. Associação Brasileira para Pesquisa da Potassa e do Fosfato, Piracicaba.

Mangal JL, Lal S (1989) Salt tolerance of onion seed crop. Hortic Sci. 64 (4): 475-477.

Marcussi FFN, Gogoy LJG, Villas Bôas RF (2004) Fertirrigação nitrogenada e potássica na cultura do pimentão baseada no acúmulo de N e K pela planta. Irriga. 9 (1): 41-51.

Ojala JC, Jarrel WM, Menge JA, Johnson ELV (1983) Influence of mycorrhizae funghi on the mineral nutrition and yield of onion in saline soil. Agron J. 75: 255-259.

Plaut Z, Edelstein M, Ben-Hur M (2013) Overcoming salinity barriers to crop production using traditional methods. Crit Rev Plant Sci. 32: 250-291.

Porto DRQ, Cecílio Filho AB, Vargas AMPF (2007) Acúmulo de macronutrientes pela cultivar cebola superex estabelecida pela semeadura direta. Cienc Rural. 37 (4): 949-955.

Rengasamy P, Chittleborough D, Helyar K (2003) Root-zone constraints and plant-based solutions for dryland salinity. Plant Soil. 257 (2): 249-260.

Sivritepe HO, Sivritepe $\mathrm{N}$ (2007) $\mathrm{NaCl}$ priming affects salt tolerance of onion (Allium cepa L.) seedlings. Acta Hortic. 729: 157-159.

Taiz L, Zeiger E (2004) Plant Physiology, 3 edn. Sinauer Associates, Sunderland.

Thomas JR (1980) Osmotic and specific salt effects on growth of cotton. Agron J. 72: 407-412.

Vidigal SM, Pedrosa MW, Fonseca MS, Santos IC (2010) Adubação com nitrogênio em cobertura na produção de cebola. Hortic Bras. 28 (2): 3705-3711.

Wiedenfeld R (1994) Nitrogen rate and timming effects on onion growth and nutrient uptake in a subtropical climate. Subtrop Plant Sci. 46: 32-37.

Wimmer MA, Muhling KH, Lauchli A, Brown PH, Goldbach HE (2003) The interaction between salinity and boron toxicity affects the subcellular distribution of ions and proteins in wheat leaves. Plant Cell Environ. 26: 1267-1274.

Yahya A (1998) Salinity effects on growth and on uptake and distribution of sodium and some essential mineral nutrients in sesame. J Plant Nutr. 21 (7): 1439-1451.

Zink FM (1962) Growth and nutrient absorption of green bunching onions. P Am Soc Hortic Sci. 80: 430-435. 